\title{
DOMINIK BORAWSKI
}

Instytut Pedagogiki i Psychologii, Uniwersytet Jana Kochanowskiego w Kielcach Institute of Pedagogy and Psychology, The Jan Kochanowski University in Kielce e-mail: dominikborawski@gmail.com

\section{A Dialogical Approach to the Identity Dilemmas of Young Adults}

\begin{abstract}
The developmental tasks of early adulthood can be considered not only in terms of achieving goals related to family, social and professional life, but also in the context of changes in the further development of identity. This position is based on an assumption that the processes behind the formation of identity in early adulthood are linked with its reconstruction leading towards multiaspectedness and flexibility. From the dialogical point of view, the dynamic evolution of identity in the period of early adulthood is a result of 1) many new I-positions being developed, 2) active processes of positions within the dialogical self being adopted and changed. Additionally, the various I-positions of the self have available different points of view. The confrontation among them can be experienced as an identiy dilemma. Four such dilemmas are discussed, based on the theories of Erikson, the Newmans, and Levinson, i.e. exploration vs. commitment, now vs. the future, dependence vs. independence, work vs. family.
\end{abstract}

Keywords: dialogical self, identity, identity dilemmas, developmental tasks, early adulthood.

Słowa kluczowe: dialogowe ja, tożsamość, dylematy tożsamościowe, zadania rozwojowe, wczesna dorosłość.

\section{INTRODUCTION}

Can we present the dilemmas faced by young adults from the perspective of dialogical processes of negotiating points of view, exchanging meanings, and a dialectical approach to contradictions? Such an interpretation has already been linked with middle adulthood (Oleś, Borawski, 2005), but at first glance, the challenges and dilemmas of early adulthood, compared to mid-life transformations, often described in terms of complexity and paradox, and abundant in meaningful exemplifications, seem somewhat trivial. Is it really the case that the problems of young adults can be reduced to the tasks which follow from undertaking roles related to family and professional life, and that the intricate issues of defining identity are of no concern to them?

\section{CLASSIC APPROACHES TO THE CHALLENGES OF EARLY ADULTHOOD}

It is worth noting that the time frame of early adulthood is hardly clearly specified and depends to a large extent on individual factors as well as demographic and sociocultural variables (cf. Oleś, 2011). According to some most popular conceptualizations, this period stretches between the age of 20 and 40 (Bee, 2004), 18 and 20, or 30 and 35 (Brzezińska, 2005). Most of the theoretical approaches to early adulthood do indeed see its specific nature in enhanced external activity and achieving expansive professional and family-related goals. A good example of this can be Erik Erikson's classic approach (Erikson, Erikson, 1997), according to which this period poses challenges linked to the establishment of an intimate relationship with 
another person, expressed both in physical and mental closeness, being a consequence of the solved intimacy-isolation dilemma. Robert J. Havighurst (1953) in his concept of the course of human life, captures the developmental tasks of this period in the category of activities focused on the "self - family - social and professional life" axis. Only secondarily does he mention the possibility of tensions or even internal conflict that might occur in the course of meeting these challenges as a result of experiencing three different kinds of pressure: biological, psychological and social. Barbara M. Newman and Philip R. Newman (1984) share a similar view of the developmental tasks of early adulthood. They divide them into challenges linked with marriage and bringing up children, or pursuing a professional career, adding also several more specific tasks dealing with the formation of an individualized lifestyle that requires the skill of coordinating various spheres of life, e.g. the effective functioning both at work and in the family.

\section{Early adulthood tasks and dilemmas according to Levinson}

Daniel Levinson $(1986,1996)$ presents a more multidimensional and ambiguous interpretation of early adulthood. Within his theory of the seasons of life he discusses early adulthood, giving consideration to a certain non-punctuality of developmental changes, and the theoretical possibility of living in two eras simultaneously, which is why he defines age boundaries in a more arbitrary way than other authors. These are very important transitions from one era ending to another only just beginning, which, in Levinson's view, can be compared to the seasons of the year that follow one after another (Levinson, 1996). Importantly, these periods force to some extent asking identity questions. Levinson thinks that the era of early adulthood begins with the phase of early adult transition and ends with settling down in a well-established, stabilized adulthood. Between these two periods, stabilization and peace occur interchangeably with crises resulting from various dilemmas that become increasingly existential with time. At the time of entering early adult transition (age 17-22), the main challenge is in the changed style of attachment to one's parents and in the experience of psychological separation from them. This is also the time of testing various, more or less mature working methods of adaptation to the adult world. In this way, the foundations of adult life are laid which are then developed in the period of debuting in the adult world (entering the adult world, age 22-28). At this stage, four important challenges have to be met:

- the formation of "the dream" and placing it within the structure of an individual's life,

- creating a relationship with a mentor,

- defining one's profession,

- creating a relationship based on love and starting a family.

In this period two contradictory tendencies appear. One is linked with further testing of possibilities and experiencing one's existence in the categories of abundance and diversity. The other is related to creating a stable life structure by building permanent reference points, especially in the areas of relationships with others, as well as the social and professional obligations. Entering one's thirties (age 30 transition: 29-33) is linked with the evaluation of one's goals achieved thus far, which are symbolically expressed in "the dream." An individual's insight is then broadened by a reflection on personal limitations and weaknesses. Additionally, a certain time pressure appears, expressed in a belief that this is the best time and it might be too late later on to make alternative decisions or introduce changes to one's timeline. Finally, in Levinson's view, age $33-40$ is the period of stabilizing the development of an adult person (the settling down stage), taking full responsibility for personal and professional matters, and focusing consistently on the realization of long-term goals, which are part of a life based on one's individual programme (BOOM - becoming one's own man). However, this is followed by the period of the reevaluation of goals, important identity questions, and the discovery of new personal resources within the mid-life transition (age 40-45). 


\section{The identity of young adults: stabilized or under construction?}

While the classic concepts of identity development (i.e. Marcia, 1966; Erikson, Erikson, 1997) assume that a person enters early adulthood with a fairly stable identity, in Levinson's view adult identity is continually being crystalized, developed and reconstructed. This seems to be consistent with the research data that prove the dynamic and processual nature of identity, and demonstrate, first of all, that a crisis related to the definition of one's identity often goes beyond adolescence (McAdams, de St. Aubin, Logan, 1993; Arnett, 2000; Anthis, Lavoie, 2006; Brzezińska, Kaczan, Piotrowski, Rękosiewicz, 2011), and, secondly, that even a well-formed identity can still undergo further, progressive and regressive transformations (Kroger, Martinussen, Marcia, 2010). Research based on the theory of dialogical self additionally confirms this by demonstrating that adolescents and adults show similar degree of intensity of internal identity dialogues, which aim at self-knowledge and find answers to the identity questions (Talik, Bąk, 2011). Even though it might be true that some areas of the identity reflection in adults are similar to those in the adolescents, the specific nature of early adulthood can be seen in the necessity to conduct parallel activities meant to achieve the practical life goals and those that review, define and reconstruct identity (Pulkkinen, Nurmi, Kokko, 2002). Finding yourself in the "deep waters" of duties and obligations is very different to the rather hypothetical considerations of adolescence, especially since this is a period of significant life-transitions, such as the birth of a child, marriage, embarking on a professional career - the events which, according to many researchers, may be a source of significant changes within the individual's identity (see: Cigoli, Scabini, 2006; Kerpelman, Lamke, 1997; Oleś, 2011). However, the effects of construing identity as if "as one goes" may vary: from winning the successive footholds of adulthood in the form of tangible results (work, money, marriage, children, housing) at the expense of a working, often fragmentary and superficial knowledge of yourself, to a di- verse and well-balanced identity, additionally confirmed by practical experience, professional successes and thriving family life. What is important, from the point of view of identity development, is that in this period, probably as a result of the need to reconcile multiple social roles, identity moves towards self-perception in terms of complexity or even multiplicity (especially at the level of self-concept) (Diehl, Hay, 2007). Also attributable to this period of life is the confrontation of expansive tendencies that consolidate an individual's autonomy with diverse and changing social expectations, forcing the formation of identity more in terms of dynamic diversity than stability and repeatability (Oleś, 2011).

\section{TOWARDS THE DIALOGICAL IDENTITY}

In the literature on the subject, this kind of dynamic identity is called dialogical referring to Hubert Hermans' Dialogical Self Theory (Hermans, 1996, 2003). Dialogical identity is a result of confrontation and exchange among various parts of the self, called the I-positions (Oleś, 2008). These positions have their source in socialization, each of them having a unique perspective of perceiving and interpreting experiences as well as a distinct emotional, motivational and thought patterns representing culture, community or significant other (Stemplewska-Żakowicz, 2002). The specific nature of the dialogical self is a result of a dynamic relationship between the subjective self and objective self (Hermans, Hermans-Konopka, 2010) as addressed by William James who mentioned potential rivalry and conflicts between the differrent selves (Hermans, 2001b). In Hermans' view the actually experienced subjective self can move in the imagined space of the mind, assuming various positions and giving them a voice (Hermans, 2003). The positioning process, i.e. taking a position and changing it, is incredibly dynamic because the meaning of existing positions changes depending on the context; additionally, and specifically to early adulthood, the embodying of various social 
roles results in new suitable I-positions (Hermans, 2013). Moreover, Hermans' theory clearly assumes that it is possible not only to adopt positions interchangeably, but also to simultaneously activate different voices, which can lead to ambivalent attitudes and inner conflict, on the one hand, but, on the other, provide for a multifaceted understanding of the world and the creation of a variety of interpersonal references (Oleś, 2009). The effects of identity formation are a derivative of the relationships among the positions of either domination or exchange (Hermans, 2001a; Hermans, Hermans-Konopka, 2010). Within the relationship of the first type, an identity owes its final shape to the self being dominated by one of the voices. This can be the voice which used to be most available in the past, e.g. the parental voice or one characterized by a special position in a given context, e.g. the professional self in the work context. The second alternative relationship assumes an opportunity for dialogue while identity is being constructed, as the result of consultations and the negotiation of contrasting points of view. Effectively, at least one of the original positions can be modified; original voices can be synthesized or entirely new ideas might come into view (Oleś, 2008). The relations between the positions of the self are crucial to the dialogical way of understanding identity. According to Hermans (2003) and Raggatt (2000) it is not a single position of the self that is the source of the sense of one's identity but a lot of mutually complementary or contracting voices that remain in a dialogue. Importantly, the dialogical self theory also assumes the existence of metaposition, which enables meta-reflection over the whole polyphony of the self, thus providing an individual with a sense of continuity and coherence, so characteristic of the classic ways of understanding identity. By adopting this unique viewpoint, one has an opportunity to get a bird's eye view of oneself, to see oneself as the space accomodating different positions, each with its own individual history which can be consequently reconfigured (Hermans, 1996). For example, a person may be distancing herself from some dominant or non-adaptive voice (e.g. inner critic) or intensify the role of a position that has so far been in the background. Thanks to the metaposition, it is also possible to synthesize the different points of view by reconciling them (Hermans, 1996). Michael Tomasello, Malinda Carpenter, Josep Call, Tanya Behne and Henrike Moll (2005) provided data demonstrating that simple forms of conceptualizing social interactions, simultaneously from the perspective of the first and third person, are possible even in childhood (i.e. taking into account the perspective of another person), although more complex forms of integrating different positions are probably observed only from the period of adolescence (Baresi, 2012). A recent study showed that only $32 \%$ of adolescents are capable of integrating different temporal I-positions (Łysiak, Oleś, 2017), which suggests that the process requires the participation of the post-formal operations (see Borawski, 2017) and, on a larger scale, it only takes place in adulthood. Besides the assumption regarding the existence of metaposition, several other previously presented assertions of the dialogical self theory find at least partial confirmation in the empirical research. Research to date revealed that at least some of the I-positions (e.g. I-critic) are universal and very easily identified (Bokus, Bartczak, Szymańska, Chronowska, Ważyńska, 2017), which pointed to dialogicality as a natural mode of human functioning (Puchalska-Wasyl, 2006; Tappan, 1999; van Halen, Janssen, 2004). Moreover, the experimentally activated I-positions involve different mental functions to a varied degree, which suggests that they can be viewed as relatively independent centers of the self system (Stemplewska-Żakowicz, Walecka, Gabińska, 2006; Stemplewska-Żakowicz, Zalewski, Suszek, Kobylińska, 2012). In addition, recent research on integrative and confrontative dialogues has confirmed the legitimacy of distinguishing different relations between the I-positions, and indicate their different regulatory functions (Puchalska-Wasyl, 2016). The idea itself to take dialogicality into account when explaining identity organization (Hermans, 2001c) has also been confirmed in several studies. One of them demonstrated that constructing a life story from the imagined future position intensified the identity exploration two weeks later (Batory, 2010). 
A recent study on adolescents showed that participants who successfully integrated the temporal dialogues between the I-positions representing past, present and future had higher Commitment and Exploration scores (a high score in terms of both processes indicates, according to Marcia, the grater maturity of identity), and that these scores increased after the dialogical procedure (Łysiak, Oleś, 2017). In a study conducted in a group of young adults, internal dialogical activity turned out to be an important predictor of structural changes of identity (Batory, 2014). The more dialogical the identity element was, the more central role it played in the self-defining process and manifested itself more in behavior. This suggests that dialogical activity can serve transformations into identities, so if we wished to influence the dynamics of identity in early adulthood, we should dialogically activate the content whose meaning we wish to enhance and find reflected in behavior (see Batory, Brygoła, Oleś, 2016).

\section{IDENTITY DILLEMAS OF EARLY ADULTHOOD}

Can we distinguish the universal positions of the self, responsible for developing and negotiating identity in early adulthood? Can we anticipate what course they might take and what the effects of the dialogue between them will be? Certainly when interpreting the dilemmas of young adults in a dialogical way (see Table 1) it is worth referring to the development theories discussed earlier.

Table 1. The dialogical approach to dilemmas experienced in the period of early adulthood with sample "voices"

\section{Exploration vs. commitment}

\begin{tabular}{|l|l|}
\hline Explore various possibilities. & Continue with what you have chosen. \\
You don't have to choose one solution. & You have to choose something. \\
Keep on searching. & Secure what you already know. \\
\hline
\end{tabular}

2. The now vs. the future

See where you are.

Catch the day.

Take advantage of opportunities.

Think where you want to be.

Think about the future.

Think of the consequences of your actions.

\section{Dependence vs. independence}

Trust others.

Take advantage of what others do.

Go with the trends.
Listen to your own voice.

Take advantage of your own ideas.

Do your own thing.

\section{The work vs. family}

Continue achieving as much as possible.

Only results matter.

Hard work is what makes you a better person.
Slow down and spend time with your family. Feelings are important. Family is what matters most.

Source: Author's own work.

\section{The exploration vs. commitment dilemma}

The first of the proposed dilemmas of young adults, remaining in accordance with the classic approach to identity originated by James Mar- cia (1966), is linked with the need to reconcile one's tendencies to test various possibilities as they appear at the threshold of adulthood with stability, interpreted as the effect of the necessity to make choices and become engaged in the 
activities dictated by these choices. It should be emphasized that whereas Marcia describes exploration and commitment as two basic processes in the context of the development of identity by early adulthood, current studies suggest that changes in their intensity and their interpermeation often take place also in the later period (e.g. Pulkinnen, Kolkko, 2000; Kroger, Martinussen, Marcia, 2010). Moreover, some studies revealed that only about half of young people obtain an achieved identity by early adulthood (Kroger, 2007).

From the point of view of the dialogical self, many new competing positions of the self and social roles are created in this period as a result of the performance of many different activities. Needless to say, these positions fight for mutual influence. The quest for the autonomy of each position of the self is associated with the operation of so-called centrifugal force (Hermans, Kempen, 1993). An individual can experience changeability and a multiplicity of self-concepts, moving smoothly between the points of view represented by the positions of the self linked with interests and hobbies, professional roles, intimate relationships or parental roles. Then again there is a need for consistency within the identity of the selves, under the influence of the centrifugal force, if only through searching for creative synthesis or a compromise between the positions they represent. And all this in order to be able to maintain the feeling of who one actually is while also experiencing the variety of all the manifestations of the self. The main threads of the dialogue associated with the dilemma discussed here may express themselves in questions of the type "Should I be still searching? And if so, searching for what?"; "What shall I focus on?"; "What is the best expression of me in all the things I experience?". The answers can be tracked down to different positions of the self and suggest further exploration: "continue searching," or an optimization of the option that is already well known: "secure what you already know." Each of the voices is potentially valuable and their role may change at various stages of an individual's life, depending on the context. The stability-supporting voice will make it easier to persist in task implementation, whereas the exploration-supporting voice may lead to more creative solutions or counteract boredom within the same activity.

\section{The now vs. the future dilemma}

Levinson observes that one of the most important tasks of early adulthood is formulating "the dream" and then taking steps to ensure its realization within the structure of one's life. This can be understood as undertaking an intentional dialogical activity, bringing together the positions of the self representing various temporal perspectives - present and future. In this kind of dialogue the actual self communicates with the possible self, representing a set of various desirable scripts, connected to the realization of the most important life goals. The course of such dialogue, crucial to formulating motivational attitude, can be of dynamic nature and activate various beliefs linked to the evaluation of one's chances of realizing one's dream as well as emotions, oscillating between disinclination and hope. While the focus on ideal states itself is perceived in positive terms, the exchange between the current and future-oriented perspective can lead to discomfort, which is the consequence of the activation of discrepancies in the system of self as discussed by Edward Tory Higgins (1987). Then again such dialogue can lead to the formulation of an important message that the future self can have for the present self, providing important clues from the point of view of objectives to be realized (Lewicka, 2010). Exchanges on the present-future axis have accompanied man at practically every stage of the realization of important life goals, if only in seemingly simple choices between the immediate (voice 1: "catch the opportunity") and deferred (voice 2: "think of the consequences") gratification. The skill of moving between these two perspectives provides for an ability to think long-term and act persistently. Even though the "now-the future" dilemma is a prevailing temporal reference in early adulthood, it should be mentioned that in Levinson's view the dialogue between the present and the future self can be almost equally important in the period of age 30 transition. This is often a time of critical evaluation of individual's activities 
linked with goal realization, including the efforts made for the realization of "the dream" as defined earlier. The inner critic can be heard at this point, the position of the self which is a specific representation of failures and negative opinions heard from significant others and stored in the authobiographic memory.

\section{The dependence vs. independence dilemma}

Since a great many different social roles are undertaken nowadays, experiencing complex interpersonal references and, with them, cross-referencing of various evaluations and perspectives - not only of the surrounding world but also of oneself - is characteristic of early adulthood. In practice, this implies the necessity to define oneself within the dependence vs. independence dilemma, signaled in the theories of Havighurst or Levinson. A confrontation with competing social expectations, which are often opposite as far as their content is concerned, is important in the course of implementing "the dream." The position of the self representing these expectations is the effect of incorporating messages issued by parents, teachers, various authorities, including some ideas of who you should be or become beyond the threshold of adulthood. These suggestions are usually very different to any content associated with dreams. Voices that express social expectations may become more significant at the time one fails to realize one's dreams. This is when the position of the self, representing ideal standards, can lose the fight for domination with the ought self. Another scenario is also possible, namely that in the course of the dialogue between the two positions an exchange of meanings takes place, leading to a new conclusion that expresses itself in a scenario that reconciles dreams ("do what you've always wanted to") and their responsible realization with respect for the postulates put forward by significant others ("remember your obligations.") In this way, the dialogue can produce creative links and a synthesis of knowledge-systems which hitherto might have seemed inconsistent or opposed.

Erikson refers to the issue of interpersonal references in his description of the intimacy vs. isolation contradiction (Erikson, Erikson, 1997). He sees the solution in the establishment of a mature relationship. From the dialogical point view, the contradiction expresses two opposing tendencies. One is the voice saying "be careful," calling for self-protection against potential threats from others, often representing the first disappointments in interpersonal relationships. The second expresses the need for affiliation with the message of the type "be open, get closer to the people around you." Both of these voices can be essential to shaping individualism, on the one hand, and interpersonal trust, on the other. Taking both positions into consideration in the course of dialogical exchange can lead to the building of a mature relationship with another person while also demanding that one's rights are respected. In a broader context this does not have to be only about intimate relationships with others but also about the task of building a relationship with a mentor as postulated by Levinson (1986). In this kind of relationship there is a peculiar risk of being entangled in a network of dependencies related to an easy access to ready-made, attractive programs of action presented by the mentor, creating the risk of one's own voice being suppressed. Alternatively, research (Staudinger, Baltes, 1996) suggests that engaging in dialogue, including inner dialogue, with a significant other can contribute to the formulation of more adequate solutions of life problems.

Building one's own original programme of life as postulated by Levinson requires, apart from the synthesis of cognitive perspectives suggested earlier, a clever selection of voices as valuable points of reference, a creative modification of plans suggested by significant others, balancing the effects of activities undertaken under the influence of other people's suggestions or producing one's own interpretation, but also a smart and courageous reinterpretation of others' opinions about oneself.

\section{The work vs. family dilemma}

It is widely accepted that the main developmental tasks facing a person in the period of early adulthood are related to starting a family and embarking on a professional career. As noted by 
some theoreticians (Newman, Newman, 1984; Levinson, 1990) and demonstrated by contemporary research on work-life conflicts (Demerouti, Peeters, van der Heijden, 2012) their families, and the organizations that employ them. The aim of the current review is to make a link between life and career stage, work and family conditions, and the work-family interface. The basic proposition is that life stages partly determine career development, and consequently the specific working conditions (job demands and job resources, these tasks do not always go hand in hand, and may become a source of identity dilemma (Oleś, 2011, p. 153), particularly for women in which this takes a more specific form of question about the choice between motherhood and developing a professional career (see: Gurba, 2011). According to Evangelia Demerouti, Maria C.W. Peeters and Beatrice I.J.M. van der Heijden (2012) the problem of imbalance between work and family life, which affects the entire apdulthood, is manifested most intensely at its early stage. This is due to the fact that a young person is in this period focused on the implementation of work obligations in order to demonstrate her competences and thereby prove her suitability for an organization. On the other hand, young adults face new responsibilities in family life, such as the birth of a child while they are being exposed both to high job and home demands and have no sufficient resources to meet them. The dilemma stemming from this complex situation is even more essential to the redefining of individual's identity as it involves the intersecting of the two key human needs - competence and relatedness (Ryan, Deci, 2000).

From a dialogical point of view bringing these needs together in a dialogue, conducted in conditions of a creative exchange of meanings, may lead to cooperation, which will complement the "cold" attributes of effectiveness and professionalism with the "warmer" elements that are the domain of family and self, and in effect lead to the integration of different personality resources. In the context of professional work, e.g. in trade, contacts with clients, it may be essential to introduce a dialogical combination of firm approach and empathy. In family life, on the other hand, it might be beneficial to in- clude some attributes linked with professional life, such, for example, as creativity, essential in the context of planning free time with family or friends.

\section{Potential moderators of the effects of dialogical identity (re)organization}

Even if the developmental theories to a certain extent allow for the prediction of the key thematic lines of identity dialogues, it is not obvious that in terms of self-definition this will lead to the same effects for everyone. First of all, assuming the thesis that identity transformations occur not only in adolescence but also extend to the period of adulthood, one might pose a question whether internal dialogue and its effects take a similar form at different stages of identity constructing process. The results of previous studies suggest that dialogical self-reflection becomes particularly intense with high level exploration (Batory, Brygoła, Oleś, 2016). Thus, its strong form concerns both mature identity and Marcia's moratorium period.

Additionally, however, it is worth paying attention to the fact that the effects of taking advantage of inner dialogical activity within the process of exploration may also depend on personality and cognitive factors. When it comes to personality, let us concentrate on two features, with which internal dialogue correlates positively - neuroticism and openness to experience. In people with high level of neuroticism identity dialogues may take a ruminative form (Oleś, Puchalska-Wasyl, 2012), whereas openness to experience may be conducive to creative exchange of meanings between I-positions (Puchalska-Wasyl, 2011). Moreover, cognitive operations related to post-formal thinking seem to be necessary to obtain integration effects in organizing identity (Trzebińska, Dowgiert, 2005). Considering that such properties of thinking appear only towards the end of the adolescence period, it is indirectly suggested by the results of studies which demonstrated that in adolescents compared to adults internal dialogicality is more often associated with the polarization of the opposite aspects of the self and non-adaptive rumination (Talik, Bąk, 2011), 
and only few adolescents are able to integrate the temporal I-positions (Łysiak, Oleś, 2017).

\section{CONCLUSIONS}

The aim of this article was to present the key dilemmas of early adolescence as the identity dialogues between different I-positions (Oleś, 2009). While previous research, conducted in the groups of young adults has confirmed that internal dialogical activity plays an important role in the processes of organization and reorganization of identity (Batory, Brygoła, Oleś, 2016), the content of identity dialogues in this developmental period have not been yet analyzed. On the other hand, the potential areas of adaptive challenges faced by young adults have been well articulated in the psychological theories of development, and the common occurrence of the phenomenon of inner dialogical activity suggested by the representatives of the discursive psychology allows for the assumption that the reflection over these challenges within the identity formation is at least partly dialogical.

However, it does not follow from the interpretation of the early adulthood identity dilemmas presented in this paper, that inner dialogical activity, which begins in childhood and carries on throuwghout human life, is specific to early adulthood or that deliberations about identity appear only in that developmental phase, as they are actually already present in adolescence. In fact, in terms of content, some dilemmas are only a continuation of the thoughts typical for adolescence, which is associated with a prolonged period of identity formation (i.e. exploration - commitment). Yet it may be true that due to the formation of new positions of the self, resulting form the undertaken roles and activities, this is a period of an increased importance of internal dialogism in the development of a dynamic and multifaceted identity. Just as the mid-life crisis is interpreted in dialogical categories as the suppressed and marginalized positions of the self finally getting a voice (Oleś, Borawski, 2005), early adulthood can be seen as a kind of laboratory of experience in which various contradictory and competing ideas for life are being incorporated and voiced, and also as a prelude to the processes balancing life achievement with the participation of different positions of the self.

What's more, due to the dynamics of the cognitive process and the appearance of post-formal forms of reasoning in the period of early adulthood, one can conclude that it is only at this stage that the inner dialogical activity can lead not only to the confrontation of different viewpoints, but also to their integration and the achievement of a creative synthesis of meanings within the dialectic whole (Borawski, 2017).

Investigating the issues relating to the development of the dialogical competences that can help develop a multifaceted and dynamic identity may become an interesting alternative which can contribute to the existing provisions of personal development workshops and programmes, or even managerial training. Such a programme would be linked with the development of dialogical techniques corresponding to each dilemma and the reviewing of their practical application. With consideration given to the results of research suggesting the therapeutic benefits of this type of intervention (cf. Cooper, Cruthers, 1999; Hermans, Dimaggio, 2007; Oleś, 2012) there is a chance that dialogical workshops and training sessions may be helpful in solving a broad spectrum of early adulthood problems, stemming from the open identity formula.

\section{REFERENCES}

Anthis K., Lavoie J.C. (2006), Readiness to change: A longitudinal study of changes in adult identity. Journal of Research in Personality, 40, 209-219.

Arnett J.J. (2000), Emerging adulthood: A theory of development from the late teens through the twenties. American Psychologist, 55, 5, 469-480. 
Baresi J. (2012), Time and the dialogical self. In: H.J.M. Hermans, T. Gieser (eds.), Handbook of Dialogical Self Theory, 46-63. New York, NY: Cambridge University Press.

Batory A. (2010), Dialogicality and the construction of identity. International Journal for Dialogical Science, 4, 1, 45-66.

Batory A. (2014), Reorganization of personal identity in the context of motivational dynamics and internal dialogical activity. Scandinavian Journal of Psychology, 55, 362-370.

Batory A., Brygoła E., Oleś P. (2016), Odstony tożsamości. Warszawa: PWN.

Bee H. (2004), Psychologia rozwoju człowieka. Poznań: Zyska i S-ka.

Bokus B., Bartczak M., Szymańska A., Chronowska R., Wazyńska A. (2017), The dialogical self's round table: Who sits at it and where? Psychology of Language and Communication, 21(1), 84-108.

Borawski D. (2017), Supporting the development of wisdom: The dialogical perspective. Roczniki Psychologiczne / Annals of Psychology, 20, 3, 523-538.

Brzezińska A.I. (2005), Jak myślimy o rozwoju człowieka? In: A.I. Brzezińska (eds.), Portrety psychologiczne człowieka, 5-19. Gdańsk: Gdańskie Wydawnictwo Psychologiczne.

Brzezińska A.I., Kaczan R., Piotrowski K., Rękosiewicz M. (2011), Odroczona dorosłość: fakt czy artefakt? Nauka, 4, 67-107.

Cigoli V., Scabini E. (2006), Family identity: Ties, symbols, and transitions. Mahwah, NJ: Lawrence Erlbaum Associates.

Cooper M., Cruthers H. (1999), Faciliating the expression of subpersonalities: A review and analysis of techniques. In: J. Rowan, M. Cooper (eds.), The Plural Self: Multiplicity in Everyday Life, 198-212. London: Sage.

Demerouti E., Peeters M.C.W., van der Heijden B.I.J.M. (2012), Work-family interface from a life and career stage perspective: The role of demands and resources. International Journal of Psychology, 47(4), 241-258.

Diehl M., Hay E.L. (2007), Contextualized Self-Representations in Adulthood. Journal of Personality, 75, $6,1255-1284$.

Erikson E.H., Erikson J.M. (1997), The Life Cycle Completed. New York: W.W. Norton.

Gurba E. (2011), Wczesna dorosłość. W: J. Trempała (red.), Psychologia rozwoju człowieka. Podręcznik akademicki, 287-311. Warszawa: PWN.

Halen C. van, Janssen J. (2004), The usage of space in dialogical self-construction: From Dante to cyberspace. Identity: An international Journal of Theory and Research, 4, 389-405.

Havighurst R.J. (1953), Human Development and Education. New York: Longmans \& Green.

Hermans H.J.M. (1996), Voicing the self: From information processing to dialogical interchange. Psychological Bulletin, 119, 31-50.

Hermans H.J.M. (2001a), The dialogical self: Toward a theory of personal and cultural positioning. Culture and Psychology, 7, 243-281.

Hermans H.J.M. (2001b), Mixing and moving cultures requires a dialogical self. Human Development, 44, $24-28$.

Hermans H.J.M. (2001c), Conceptions of self and identity: Toward a dialogical view. International Journal of Education and Religion, 1, 43-62.

Hermans H.J.M. (2003), The construction and reconstruction of a dialogical self. Journal of Constructivist Psychology, 16, 89-130.

Hermans H.J.M. (2013), The dialogical self in education. Journal of Constructivist Psychology, 26, 81-89.

Hermans H.J.M. Dimaggio G. (2007), Self, identity, and globalization in times of uncertainty: A dialogical analysis. Review of General Psychology, 11, 31-61.

Hermans H.J.M., Hermans-Konopka A. (2010), Dialogical Self Theory: Positioning and Counter-Positioning in a Globalizing Society. Cambridge, UK: Cambridge University Press

Hermans H.J.M., Kempen H.J.G. (1993), The Dialogical Self: Meaning as Movement. San Diego: Academic Press.

Higgins E.T. (1987), Self-discrepancy: A theory relating self and affect. Psychological Review, 94, 319-340.

Kerpelman J.L., Lamke L.K. (1997), Anticipation of future identities: A control theory approach to identity development within the context of serious dating relationships. Personal Relationships, 4, 1, 47-62.

Kroger J. (2007), Identity Dvelopment: Adolescence through Adulthood, $2^{\text {nd }}$ ed. Thousand Oaks, CA: Sage. 
Kroger J., Martinussen M., Marcia J.E. (2010), Identity status change during adolescence and young adulthood: A meta-analysis. Journal of Adolescence, 33, 5, 683-698.

Levinson D.J. (1986), A conception of adult development. American Psychologist, 41, 3-13.

Levinson D.J. (1990), A theory of life structure development in adulthood. In: C.N. Alexander, E. Langer (eds.), Higher Stages of Human Development. Perspectives on Adult Growth, 35-53. Oxford: Oxford University Press.

Levinson D.J. (1996), Seasons of a Woman's Life. New York, NY: Alfred A. Knopf.

Lewicka M. (2010), Dialogowa konfrontacja temporalnych pozycji Ja. Badanie osób w okresie połowy życia. Niepublikowana praca magisterska. Warszawa: SWPS.

Łysiak M., Oleś P. (2017), Temporal dialogical activity and identity formation during adolescence. International Journal for Dialogical Science, 1, 1-18.

Marcia J.E. (1966), Development and validation of ego - identity status. Journal of Personality and Social Psychology, 3, 5, 551-558.

McAdams D.P., de St. Aubin E., Logan R.L. (1993), Generativity among young, midlife, and older adults. Psychology and Aging, 8, 221-230.

Newman B.M., Newman Ph.R. (1984), Development through Life: A Psychosocial Approach. Homewood, Ill.: The Dorsey Press.

Oleś P.K. (2008), O różnych rodzajach tożsamości oraz ich stałości i zmianie. In: P.K. Oleś, A. Batory (eds.), Tożsamość i jej przemiany a kultura, 41-84. Lublin: Wydawnictwo KUL.

Oleś P.K. (2009). Dialogowość wewnętrzna jako właściwość człowieka. In: J. Kozielecki (eds.), Nowe idee w psychologii, 216-235. Gdańsk: Gdańskie Wydawnictwo Psychologiczne.

Oleś P.K. (2011), Psychologia człowieka dorosłego. Warszawa: PWN.

Oleś P.K. (2012), Dialogical functions of the self - implications for health. Chowanna, 38, 47-65.

Oleś P.K., Borawski D. (2005), Kryzys wieku średniego - w kierunku ujęcia dialogowego. Zeszyty Interwencji Kryzysowej, 8, 45-63.

Oleś P., Puchalska-Wasyl M. (2012), Dialogicality and personality traits. In: H.J.M. Hermans, T. Gieser (eds.), Handbook of Dialogical Self Theory, 241-252. Cambridge, UK: Cambridge University Press.

Puchalska-Wasyl M. (2006), Nasze wewnętrzne dialogi. O dialogowości jako sposobie funkcjonowania czlowieka. Wrocław: Wydawnictwo Uniwersytetu Wrocławskiego.

Puchalska-Wasyl M. (2011), Internal dialogical activity: Types and personality correlates. In: R.A. Jones, M. Morioka (eds.), Jungian and Dialogical Self Perspectives, 100-116. Basingstoke: Palgrave Macmillan.

Puchalska-Wasyl M. (2016), Coalition and opposition in myself? On integrative and confrontational internal dialogs, their functions, and the types of inner interlocutors. Journal of Constructivist Psychology, 29, 2, 197-218.

Pulkkinen L., Nurmi J.E., Kokko K. (2002), Personal goals and well-being. In: L. Pulkkinen, A. Caspi (eds.), Paths to Successful Development, 331-352. Cambridge: Cambridge University Press.

Raggatt P.T.F. (2000), Mapping the dialogical self: Towards rationale and method of assessment. European Journal of Personality, 14, 65-90.

Ryan R.M., Deci E.L. (2000) Self-determination theory and the facilitation of intrinsic motivation, social development, and well-being. American Psychologist, 55, 68-78.

Staudinger U.M., Baltes P.B. (1996), Interactive minds: A facilitative setting for wisdom-related performance? Journal of Personality and Social Psychology, 71, 746-762.

Stemplewska-Żakowicz K. (2002), Umysł dyskursywny. Propozycje teoretyczne podejścia dyskursywnego w psychologii. In: I. Kurcz, J. Bobryk (eds.), Psychologiczne studia nad językiem i dyskursem, 195-228. Warsaw: Wydawnictwo Instytutu Psychologii PAN.

Stemplewska-Żakowicz K., Walecka J., Gabińska A. (2006), As many selves as interpersonal relations (or maybe even more). International Journal for Dialogical Science, 1, 1, 71-94.

Stemplewska-Żakowicz K., Zalewski B., Suszek H., Kobylińska D. (2012), Cognitive architecture of the dialogical mind: An experimental approach. In: H.J.M. Hermans, T. Gieser (eds.), Handbook on the Dialogical Self, 264-283. Cambridge: Cambridge University Press. 
Talik W., Bąk W. (2011), Struktura systemu Ja a wewnętrzna aktywność dialogowa. Ujęcie w perspektywie rozwojowej. W: P.K. Oleś, M. Puchalska-Wasyl, E. Brygoła (red.), Dialog z samym soba, 252-273. Warszawa: Wydawnictwo Naukowe PWN.

Tappan M.B. (1999), Authoring a moral self: A dialogical perspective. Journal of Constructivist Psychology, $12,117-131$.

Tomasello M., Carpenter M., Call J., Behne T., Moll H. (2005), Understanding and sharing intentions: The origins of cultural cognition. Behavioral and Brain Sciences, 28, 675-735.

Trzebińska E., Dowgiert A. (2005), Polipsychizm: pożytki i koszty związane z wielowymiarowością tożsamości. Przegląd Psychologiczny, 48, 1, 75-94. 